\title{
RECOVERY OF LOGGING RESIDUES THROUGH BALER ON FORWARDER: EXPERIENCE WITH Eucalyptus globulus IN CHILE ${ }^{1}$
}

\author{
Eduardo Acuña ${ }^{2 *}$, Hector Villalobos ${ }^{2}$, Jorge Cancino² and Pablo Mena²
}

\footnotetext{
${ }^{1}$ Received on 25.05.2015 accepted for publication on 06.11.2017.

${ }^{2}$ Universidad de Concepción, Facultad de Ciencias Forestales, Concepción Chile. E-mail: <edacuna@udec.cl>, $<$ hvillalobos@orioncapital.cl>,<jcancino@udec.cl> and <pablomena@udec.cl>.

*Corresponding author.
}

\begin{abstract}
This study presents results of tests on the recovery of Eucalyptus globulus logging residues. Leftovers were packed with an ENFO-2002 baler on a forwarder, taking advantage of a cut-to-length harvesting system for two conditions of residual biomass, i.e., with and without bark. A continuous field study was carried out, controlling 16.4 scheduled hours in seven days. Delays in the operation stemmed mainly by the visits of the client company and supervision by phone. The baler had an average utilization capacity of $81 \%$ for both evaluated conditions and produced an average of 36.2 bales with and 22.2 bales without bark per productive area. An average dry biomass productivity of 5.85 and $5.46 \mathrm{Mg} \mathrm{h}^{-1}$ was reached for similar conditions of residual biomass. Significant differences emerged when the type of harvesting was compared to mean dry weight, between types of harvesting, and mean baling time. Thus, the presence of bark in the logging residues of E. globulus increases the productivity of the baler.
\end{abstract}

Keywords: Biomass; Eucalyptus globulus; Residue baling.

\section{RECUPERAÇÃO DE RESÍDUOS DA COLHEITA ATRAVÉS ENFARDADEIRA EM FORWARDER: EXPERIÊNCIA EM Eucalyptus globulus NO CHILE}

\begin{abstract}
RESUMO - Neste estudo, os resultados de testes realizados na recuperação de resíduos da coleheita de Eucalyptus globulus são apresentados. Estes resíduos foram embalados por meio de uma enfardadeira ENFO-2002 em um forwarder, aproveitando um corte para sistema de processamento de comprimento para duas condições de biomassa residual (com e sem casca). Um estudo de campo contínuo foi realizada, controlando aproximadamente 16,4 horas programadas em sete dias. Dias perdidos foram causados principalmente pelas visitas da empresa cliente e supervisão pelo telefone. A enfardadeira tinha uma capacidade de utilização de $81 \%$ em média para ambas as condições avaliadas. Esta enfardadeira produziu uma média de 36,2 e 22,2 fardos por área produtiva para com ou sem condições de casca, respectivamente. Uma produtividade média de biomassa seca de 5,85 e 5,46 Mg hora ${ }^{-1}$ foi atingido por condições semelhantes de biomassa residual. Foram encontradas diferenças significativas quando o tipo de utilização foi comparado com o peso médio seco e entre o tipo de utilização e o tempo médio de enfardamento. Assim, a presença de resíduos de casca no registro de $\boldsymbol{E}$. globulus aumenta a produtividade da enfardadeira.
\end{abstract}

Palavras-Chave: Biomassa; Eucalyptus globulus; Enfardamento resíduo. 


\section{INTRODUCTION}

The use of biomass has become important for mitigating the effects of climate change, and particularly forest biomass has proved key for renewable energy generation (Intergovernmental Panel on Climate Change, 2011). For instance, the European Union, to achieve its ambitious climate and energy objectives for 2020 , promotes bioenergy as a crucial source, because of its renewable and carbon neutral nature (European Commission, 2014). European legislation strongly supports residues including waste from logging operations as raw materials for bioenergy. Thus, in the European Union biofuels represent a growing source for electricity generation, with more than $50 \%$ coming from timber and residues of forest harvesting. In Sweden, over $90 \%$ of biofuels derive from timber and forest logging residues (European Biomass Association, 2012).

Such residues may represent a substantial change in the total biomass available in a place (Brand et al., 2014) that can be used for energy production via appropriate means of transformation. According to Hunter et al. (1999), the density of the residues crucially affects the cost/benefit analysis of different harvesting systems. Increasing both density and homogeneity of residues in the forest becomes therefore critical, to lower logistics costs and management efforts. On the other hand, if the purpose is to increase the use of bioenergy to reduce pressure on the environment, it becomes important to design the production system in a way to minimize the environmental burden (Lindholm et al., 2010).

Both America and Europe have begun to use balers for recovering residues from forests. These balers produce so-called "composite residue logs", compact bales of approximately 2.5 to $3 \mathrm{~m}$ in length and 60 to $90 \mathrm{~cm}$ in diameter. The resulting bales of timber residues can be handled with conventional logging equipment, such as a forwarder for logging for a lumbering timber court and standard trucks for transport to the plant. Composite residue logs can be crushed immediately with a stationary crusher, more efficient and economical than mobile models, before processing in the plant (Asikainen et al., 2001).

In particular, studies have been carried out in Germany (Neff et al., 2006), Spain (Canga et al., 2009), the US (Earl, 2006; Patterson et al., 2008; Meadows et al., 2011), Finland (Laitila et al., 2009; Kärhä et al., 2011; Nuutinen et al., 2011; Laitila et al., 2013), France
(Cuchet et al., 2004), Italy (Spinelli et al., 2007; Spinelli and Magagnotti, 2009; Spinelli et al., 2012a, 2012b), Poland (Chlebowski and $\mathrm{Jab}^{3}$ oñski, 2012), and Sweden (Johansson et al., 2006; Lindroos et al., 2010). All these studies have focused on investigating the operation of balers mounted on forwarders, equipment capable of accessing the logging site directly, and using conifer residues as raw materials, with the exception of Cuchet et al. (2004), who also investigated the productivity of Pinus pinaster de Castanea sativa L., Ostrya carpinifolia L. and Populus $\times$ Euroamericana; and Canga et al. (2009) and Sánchez et al. (2011) on residues of E. globulus.

According to Cuchet et al. (2004), the main parameters that affect the productivity of baling are amount of residues available per unit area $\left(\mathrm{Mg} \mathrm{ha}^{-1}\right)$, their average size and distribution in the forest. Kärhä et al. (2011) compared the costs of the supply chain based on the baling of the whole tree and the supply chains of pulpwood and energy wood. They concluded that the baling of the whole tree carries lower operational costs in the first thinning. Spinelli and Magagnotti (2010) tested a baler mounted on a truck in the Italian Alps, obtaining an average productivity between 14 and 22 bales per productive hour of the machine (PHM), or between 10 and 15 bales per scheduled hour, or presence, of the machine (SMH). Biomass production fluctuated from 3 to $4.3 \mathrm{Mg}$ of dry biomass per SMH. According to these authors, if the machine is used at least $800 \mathrm{SMH}_{\text {year }}{ }^{-1}$, baling costs would fluctuate between 7 and $9 € \mathrm{MWh}^{-1}$, well within the range of profitability indicated by Nordic studies. Although baling represents an additional cost in the "slash-to-chip" chain, it has the advantage of providing an efficient storage during winter, and turns out crucial where fuel biomass offer and supply are diachronic.

In Chile, during the last decade the productivity of forest machinery (i.e., harvesters, forwarders and skidders), has been researched in several studies (Bustos et al., 2010; Bustos and Egan, 2011; Acuña et al., 2013). Nonetheless, few productivity studies on forest machinery in harvests of logging residues have been carried out. Acuña et al. (2017) studied residues of Pinus radiata on 19 forest farms, recovering residues with the assistance of two excavators, one grapple skidder and one crusher.

Logging residues are an important source of energy in Chile. Rising use of forest biomass for energy purposes, as well as incrementing transport costs are forcing biomass suppliers to better manage the supply chain.

Revista Árvore. 2017;41(5):e410512

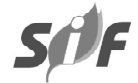


Moisture content, densification and productivity in the recovery of the logging residues constitute major concerns for the providers. However, experimental studies have shown that Eucalyptus residues have advantages over those of Pinus radiata, because the latter are brittle to low moisture contents, getting lost in the structure of the bales.

Below, recent tests of a baling system of logging residues are described, with the overall aim to evaluate the productivity of an ENFO-2000 baler on a Valment 890-2 forwarder regarding the recovery of Eucalyptus globulus logging residues. To this end, the cut-tolength harvesting system for two conditions - with and without bark - of the residual biomass was used.

\section{MATERIALAND METHODS}

\subsection{Description of the study area}

The recovery study of logging residues was executed on two sites located in important forestry sectors. On Santa Elena (715051.92 - 5820748.68 UTM) and Rehuen (741418.41 - 5817575.24 UTM) farms, in the province of Malleco, Araucanía Region, Eucalyptus globulus was planted in 1998 and 2000, respectively.

Santa Elena has a topography of rolling hills and a mean slope of $17 \%$, a maximum one of $35 \%$, and a minimum one of $7 \%$. Pre-harvest inventory projected a density of 1,104 trees per hectare, a volume of 254 $\mathrm{m}^{3} \mathrm{ha}^{-1}$ and a quadratic medium diameter of $19.9 \mathrm{~cm}$. A cut-to-length harvesting system was used, with tumbling and buckling with chainsaw without debarking. The logging residues were arranged in manually created rows. On the other hand, Rehuen farm has a topography of rolling hills with a mean slope of $10 \%$, a maximum one of $20 \%$ and a minimum one of $0 \%$. Pre-harvest inventory projected a density of 1,192 trees ha-1, a volume of $223 \mathrm{~m}^{3} \mathrm{ha}^{-1}$ and quadratic mean diameter of $18.9 \mathrm{~cm}$. The plantation was also harvested with a cut-to-length harvesting system, and included a caterpillar harvester (Tigercat shovel logger LS855C) and a claw skidder (Tigercat grapple skidder 625). Logging residues were not organized in any way and placed as the harvester put them.

\subsection{Description of the machinery}

The baler on a forwarder is composed of two independent units which belong together. The base machine is a Model 890.2 Valmet forwarder, with a set of wheels for movement. This machinery hauls and generates the hydraulic and electric power necessary for operation and was selected to work in areas of steep slopes with difficult access considering year-round operation. On the other hand, the baler (Figure 1B) does the stacking, tying and cutting of the bales. The set is called baler on forwarder, or simply the baler.

The baler is a new ENFO-2000 machine of Spanish origin, manufactured by Talleres Ramón Castro Company. It has a four-roller feeding unit (two horizontal and two vertical), a compacting unit of fixed press - where the first pressing is performed - and a mobile coach (mobile press + tying unit) which performs the final pressing process. According to the manufacturer, a reduction of $80 \%$ in biomass volume is achieved by means of a shear bake cutting unit in the pressing and tying process of bales. Finally, the machinery's operation is managed via an electronic process unit. The baler has no restrictions in terms of length of bale, because it is programmable. It has a weight with a quick snag of $11,500 \mathrm{~kg}$, a height of 2,405 mm and width of 2,586 $\mathrm{mm}$. The length of the machine in operation is 7,020 $\mathrm{mm}$, and the length of the equipment in transportation conditions is $5,542 \mathrm{~mm}$. For operation, a maximum hydraulic pressure of $255 \mathrm{~kg} \mathrm{~cm}^{-2}$ and a minimum flow of 175 $1 \mathrm{~m}^{-1}$ are required.

\subsection{Time study}

For the analysis of productivity, a continuous time study was performed. Each work cycle was divided into work elements that describe the beginning and the end of each cycle (Table 1) and classified as service times, or uptimes, following the terminology suggested by the IUFRO Work Group (Björheden and Thompson, 1995). Because two tasks can be performed simultaneously in the work cycle of the baler (i.e., grouping and movement), an order of priority was established to assign the tasks during the time studies. Data acquisition was performed by means of the ForestTime Android application.

Working times were registered for the entire harvesting system of the residues and the preparation and arrangement of the bales. To perform this task, the activities of the machine were observed daily and used times were registered, according to the method proposed by Magagnotti and Spinelli (2012). They suggest to include only the events of delay that occur within a maximum duration of 15 minutes. Cycle times of the 
baler were divided into six activities: baling, biomass loading, unloading and accommodation of bales, movement, empty trip and lost time (Table 1).

To determine the temporary performance of the baler, three indicators were considered: Mechanical availability (MA), machine utilization (MU), and utilization capacity of the machine (CCU). According to Van Daele (2000), mechanical availability refers to fraction of time in the workplace during which the equipment is mechanically available and capable of performing a productive task; machine utilization relates to the percentage of time the machine in the workplace is performing the task for which it was designed. Finally, utilization capacity measures the degree of total time the machine needs to carry out the task, denominated 'uptime' by Björheden and Thompson (1995). The latter is not a measure of machine efficiency, but a measure of the regular working hours of operation against the total scheduled time available. Thus, the performance indicators are:

- Mechanical availability = Eq-1

$$
\begin{gathered}
M A(\%)=\frac{W P-S T}{W P} \times 100 \\
\cdot \text { Machine utilization }=\mathrm{Eq}-2 \\
M U(\%)=\frac{P W}{W P} \times 100 \\
\text { - Capacity utilization }=, \text { Eq-3 } \\
C U(\%)=\frac{W P}{T T} \times 100
\end{gathered}
$$

where WP represents workplace time, ST service time, $P W$ the productive work time, and TT total time.

\subsection{Registry variables}

For the different analyses, the number of bales elaborated during the scheduled time, as well as the daily registry of their bulk volume, was considered production. Therefore, the availability of biomass per surface unit was determined based on the relation between the total bulk volume of each task/farm and the corresponding surface on which the recovery of logging residues occurred. Volume was determined for each of the bales elaborated by the machine by means of the Smalian formula (Husch et al., 2003):Eq-4,

$$
V=\left(\frac{A_{1}+A_{2}}{2}\right) \times L
$$

Revista Árvore. 2017;41(5):e410512 where $V$ is the volume (bulk $\mathrm{m}^{3}$ ), $A_{l}$ constitutes the lower area of the bale $\left(\mathrm{m}^{2}\right), A_{2}$ the upper area, and $L$ the length of the bale $(\mathrm{m})$.

To determine moisture content, dry weight and volume per bale, a pre-sampling of bales was performed for each type of task. Sampling size was 19 bales for the task with bark and 15 bales for the task without bark, aiming for an error lower than 10\%. Volume (bulk m³), granulometry and moisture content per particle size class after being crashed ex situ was measured for each selected bale. Particle size ranges were established in function of the potential use of these residues as fuel in boilers, namely: coarse $(>5 \mathrm{~cm})$, medium $(<5$ $->1 \mathrm{~cm})$ and small $(>1 \mathrm{~cm})$ biomass.

To determine the moisture content per granulometry type, samples were stored in hermetic bags for transportation to the laboratory. Green weight (as received) was registered from each sample and the samples were dried during 24 hours in an oven at 105 $\pm 2{ }^{\circ} \mathrm{C}$ to determine the moisture content. Once the drying process ended, samples were weighed again to record dry weight $(\mathrm{g})$. With all these data, the dry weight was defined according to EN 14774-1:2009 standard. Moisture content in percent was calculated according to the following equation:Eq-5

$$
\% M C_{d b}=100 \times \frac{M C}{W_{d}}
$$

thus

$$
\% M C_{d b}=\frac{W_{g}-W_{d}}{W_{d}} \times 100
$$

where, $\% M C_{d b}$ represents moisture content in percent, dry basis matter, $M C$ is the moisture content (g), $W_{g}$ green weight (initial) of the sample (g), and $W_{d}$ constitutes the dry weight (final) of the sample (g).

The productivity of the baler was determined in function of productive hours of the machine, i.e., the time in which the tasks for which the machine was designed were carried out, considering aspects such as delay times, breaks, etc.

\subsection{Data analyses}

An analysis of variance (ANOVA) was conducted through the PROC GLM SAS module for non-balanced data (Sas Institute Inc., 2014) to test the effect of the forest harvesting system, with and without bark, on 
the mean volume, mean dry weight per bale and mean time per baling cycle. In all cases the assumption of normality, constant variance and independency of errors were met. An alpha of 0.05 was used to determine significant differences.

\section{RESULTS}

\subsection{Utilization times of residual biomass}

A total of 116.32 scheduled hours during 13 working days were controlled. Of these, 70.77 hours corresponded to tasks with bark and 45.55 without bark. Tasks were performed all days by the same operator and no disturbances due to bad weather arose.

Non-work times for the task with bark corresponded to $15.2 \%$, without interferences, and alterations occurred by phone supervision (Figure 1A). For the task without bark, non-work times were $11.2 \%$; breaks, interferences and work disturbances reached $8.5 \%, 3.0 \%$ and $0.6 \%$ of total operation time, respectively (Figure 1B). In addition, delays in the operation stemmed mainly from visits of the contracting company and phone supervision.

The time percentage of operation activities of the baler was equal for both types of task. This percentage relates to the moment a bale is cut by the shear of the machine and leaving it, until the next one is cut - a time element performed together with the biomass loading, unloading, bale arrangement and the movement of the forwarder. The difference between both tasks arose mainly due to complementary and maintenance times. Although it they occurred for the same reasons for both tasks, complementary times occurred more in the task without bark, where the hopper presented a longer time being obstructed by biomass accumulation. This could be attributed to the presence of bark in the residues.

According to the performance indicators evaluated, the ENFO-2000 baler on forwarder showed mechanical availability of $87.7 \%$ and $89.9 \%$ for tasks with bark and without bark, respectively. The utilization of the machine amounted to $82.8 \%$ and $85.6 \%$ in tasks related to the baling itself, and a utilization capacity of $81.1 \%$ and $81.7 \%$ in both tasks, respectively.

\subsection{Performance of harvested residual biomass}

The dimensions of the bales are variable because they come from different types of processed raw materials and from different lengths. During the analyzed process, the recovery of the baled residues reached $2,118.5$ bulk $\mathrm{m}^{3}, 1,295.9$ bulk $\mathrm{m}^{3}(61.2 \%)$ in the task with bark, and 822.6 bulk m$^{3}(38.8 \%)$ in the task without bark, with mean moisture of $21.8 \%$ and $18.2 \%$, respectively (Table 2 ).

The optimal particle size range amounts to fuel chips size between 1 and $5 \mathrm{~cm}$. A mean of $11.8 \%$ and $25.0 \%$ of the raw material within this range was recorded for the task with and without bark, respectively. The size of chips greater than $5 \mathrm{~cm}$ was considered oversize and modified to reduce particle size and reincorporate them into the process, which involves adding a new cost. For fuel, chips larger than $5 \mathrm{~cm}$ caused problems in the dragging systems of the material to the boiler, because they lock the drive chains. On the other hand, chips smaller than $1 \mathrm{~cm}$ are less desirable because they present a minimum residence time in the grid, and if they are too dry explosive behavior can arise at combustion time. On average, this range was present in $65.9 \%$ of the task with bark, and $35.5 \%$ in the task without bark (Table 3).

When mean volume of the bales $\left(\mathrm{m}^{3}\right)$ was compared to the type of harvesting system (with and without bark) in each period, no statistically significant differences $(P=0.1254)$ appeared. Statistically significant differences showed, however, between type of harvesting system and mean dry weight of bales $(\mathrm{Mg})(P=0.0017)$, and type of harvesting system and mean baling time (in seconds) $(P<0.0001)$ (Table 4$)$. These results suggest that the utilization of trees without bark improves the baling performance of residues, and the presence of eucalyptus bark increases the density of bales and therefore their dry weight. Similarly, the mean moisture content of the baled biomass carries importance for the cost of the final transport, because trucks reach their maximum legal payload with wet materials without reaching their maximum volumetric capacity.

Thus, the bale could produce an average of 26.2 and 22.2 bales $\mathrm{hr}^{-1}$ in tasks with and without bark, respectively, with a productivity of 185.1 and 137.1 bulk $\mathrm{m}^{3} \mathrm{hr}^{-1}$. These figures correspond to $5.85-5.46$ $\mathrm{Mg} \mathrm{hr}^{-1}$ for both tasks, respectively.

\section{DISCUSSION}

Productivity levels of the baler are slightly lower than those in studies carried out for the same baler and species by Canga et al. (2009) with yields between 


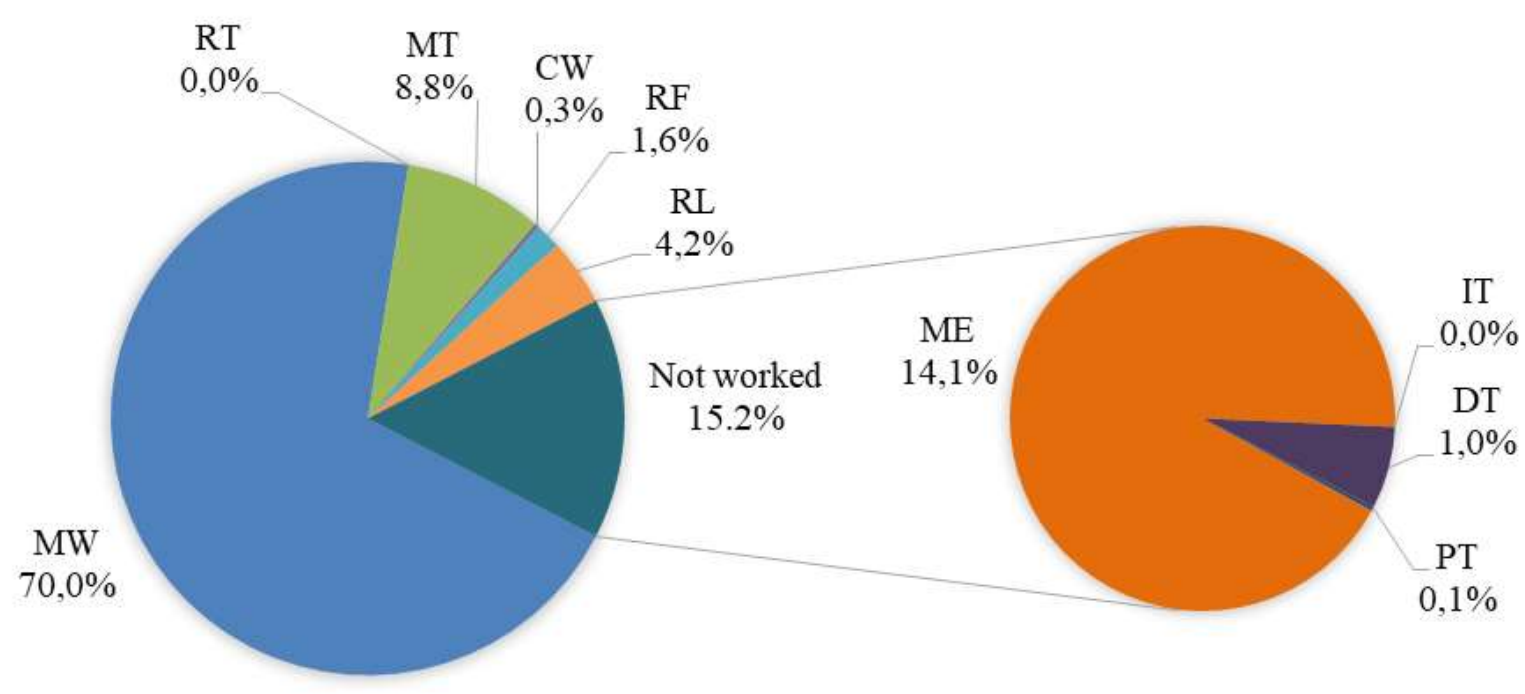

A)

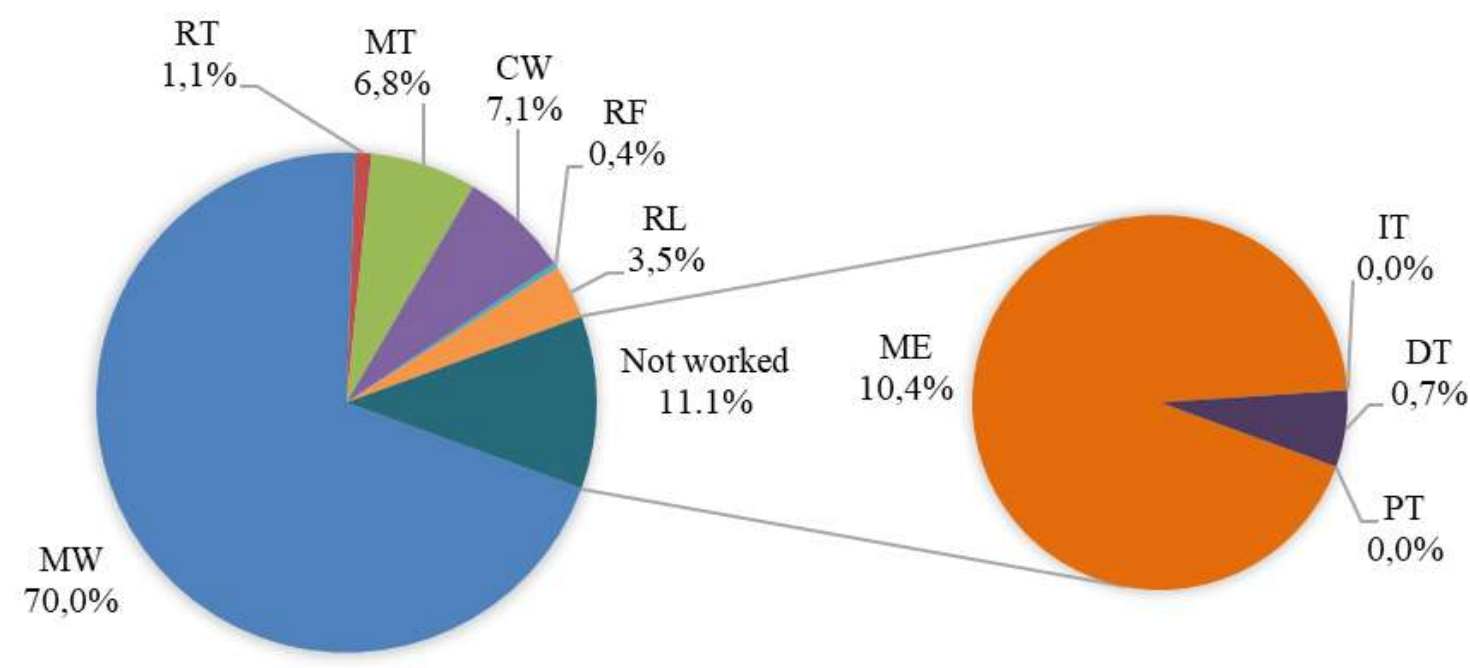

B)

Figure 1 - Time used by the baler (\%), A) with bark, B) without bark.

Figura 1 - Tempo utilizado pela enfardadeira (\%), A), com casca e B), sem casca.

Revista Árvore. 2017;41(5):e410512 
Table 1 - Work elements of the baler in the recovery of forest logging residues.

Tabela 1 -Elementos de trabalho da enfardadeira na recuperação de resíduos da colheita.

\begin{tabular}{ll}
\hline Work elements & \multicolumn{1}{c}{ Description } \\
\hline Baling & $\begin{array}{l}\text { From the shearing machine cutting the bale and leaving it until the next bale is cut. This } \\
\text { time element is performed in conjunction with the biomass loading, unloading and arrangement } \\
\text { of bales and movement of the machine, with greater duration than the other activities together. } \\
\text { From when the claw starts, picking the biomass up from the ground to bring it into the mouth } \\
\text { of the baler feeder, releasing the biomass. The process may include several sub-cycles and } \\
\text { the time element when the claw is moved to the outlet of the baler, taking it to put it on } \\
\text { the ground or stack it. }\end{array}$ \\
changes & $\begin{array}{l}\text { From when the bale leaves the machine, being taken by the claw and put on the ground } \\
\text { or being stacked. This time element may or may not be performed, depending on the } \\
\text { characteristics of bales and the ground, because the machine may drop bales without } \\
\text { and arrangement } \\
\text { unloading and accommodating them. } \\
\text { Performed together with the tasks described above. Corresponds to the movement performed } \\
\text { by the machine, looping for biomass to be baled. } \\
\text { Movement from the machine's parking slot before starting daily tasks until the beginning } \\
\text { the baling process. } \\
\text { Empty trip }\end{array} \quad \begin{array}{l}\text { Corresponds to all e.g., operational, mechanical or maintenance related eventualities that stop } \\
\text { the productive process. } \\
\text { Molay }\end{array}$ \\
$\begin{array}{l}\text { Movement time from when the machine finishes its working day and the production of bales } \\
\text { is stopped until the machine is parked in a designated area.Travel time from when the machine } \\
\text { stops is also considered. }\end{array}$
\end{tabular}

Table 2 - Mean yield in volume and green weight per bale.

Tabela 2 - Rendimento médio em volume e peso verde por fardo.

\begin{tabular}{lcccccc}
\hline Task & Statist & $\begin{array}{c}\text { Minor } \\
\text { diameter }(\mathrm{cm})\end{array}$ & $\begin{array}{c}\text { Major } \\
\text { diameter }(\mathrm{cm})\end{array}$ & $\begin{array}{c}\text { Length } \\
(\mathrm{cm})\end{array}$ & $\begin{array}{c}\text { Volume } \\
\left(\mathrm{m}^{3} \text { bale }^{-1}\right)\end{array}$ & $\begin{array}{c}\text { Green } \\
\left(\mathrm{Mg}^{\text {bale }}\right)\end{array}$ \\
\hline With bark & Minimum & 54.2 & 71.5 & 220.0 & 0.85 & 0.173 \\
& Mean & 63.6 & 78.3 & 248.0 & 0.99 & 0.252 \\
& Maximum & 74.5 & 82.6 & 262.0 & 1.15 & 0.338 \\
& Standard deviation & 5.5 & 3.7 & 10.7 & 0.10 & 0.050 \\
\hline Without bark & Minimum & 59.0 & 70.5 & 198.0 & 0.77 & 0.236 \\
& Mean & 70.0 & 80.4 & 235.1 & 1.06 & 0.313 \\
& Maximum & 88.7 & 96.0 & 251.0 & 1.26 & 0.453 \\
& Standard deviation & 8.5 & 8.2 & 15.5 & 0.14 & 0.056 \\
\hline
\end{tabular}

Table 3 - Percentage disposition of the wet weight of the compacted material, moisture content and mean dry biomass per bale.

Tabela 3 - Disposition percentagem do peso húmido do material compactado, teor de umidade e de biomassa seca média porfardo.

\begin{tabular}{|c|c|c|c|c|c|c|}
\hline \multirow{2}{*}{ Farm } & \multirow{2}{*}{ Statist } & \multicolumn{3}{|c|}{ Particle size (\%) } & \multirow{2}{*}{$\begin{array}{c}\text { Moisture } \\
\text { content }\end{array}$} & \multirow{2}{*}{$\begin{array}{c}\text { Dry } \\
\text { biomass }\end{array}$} \\
\hline & & Small & Medium & Coarse & & \\
\hline & & $(<1 \mathrm{~cm})$ & $(<5->1 \mathrm{~cm})$ & $(>5 \mathrm{~cm})$ & $(\%)$ & $\left(\mathrm{Mg} \mathrm{bale}^{-1}\right)$ \\
\hline \multirow[t]{4}{*}{ With bark } & Minimum & 38.3 & 3.6 & 7.2 & 13.7 & 0.208 \\
\hline & Mean & 65.9 & 11.8 & 22.3 & 18.3 & 0.264 \\
\hline & Maximum & 86.3 & 22.6 & 47.4 & 27.5 & 0.369 \\
\hline & Standard deviation & 16.0 & 5.8 & 13.4 & 4.9 & 0.041 \\
\hline \multirow[t]{4}{*}{ Without bark } & Minimum & 11.4 & 12.5 & 0.0 & 14.2 & 0.134 \\
\hline & Mean & 35.5 & 25.0 & 39.5 & 21.8 & 0.208 \\
\hline & Maximum & 71.7 & 36.1 & 71.4 & 31.2 & 0.285 \\
\hline & Standard deviation & 17.3 & 8.6 & 21.0 & 5.9 & 0.045 \\
\hline
\end{tabular}


Table 4 - Analysis of variance of harvesting system effect on the mean volume, mean dry weight of bale and mean time per baling cycle.

Tabela 4 - Análise de variância do efeito do tipo de utilização sobre o volume médio, peso seco médio do fardo e tempo médio por ciclo de enfadamento.

\begin{tabular}{|c|c|c|c|c|c|c|}
\hline Variable & Source & DF & Sum of squares & Mean square & F-Value & $\operatorname{Pr}>F$ \\
\hline Volume per & Task & 1 & 0.03400 & 0.03400 & 2.48 & 0.1254 \\
\hline \multirow[t]{2}{*}{ bale $\left(\mathrm{m}^{3}\right)$} & Error & 32 & 0.43930 & 0.01373 & & \\
\hline & Total & 33 & 0.47330 & & & \\
\hline Dry weight & Task & 1 & 0.02055 & 0.02055 & 11.7 & 0.0017 \\
\hline \multirow[t]{2}{*}{ per bale $(\mathrm{Mg})$} & Error & 32 & 0.05609 & 0.00175 & & \\
\hline & Total & 33 & 0.07664 & & & \\
\hline \multirow[t]{3}{*}{ Baling time (sec) } & Task & 1 & 290.773 .06 & $290,773.06$ & 49.38 & $<0.0001$ \\
\hline & Error & 2.269 & $13.361,579.71$ & $5,888.75$ & & \\
\hline & Total & 2.270 & $13.652,352.78$ & & & \\
\hline
\end{tabular}

27-31 bales hr-1, Sánchez et al. (2011) with 35 bales $\mathrm{hr}^{-1}$ and Sánchez-García et al. (2015) with 26.3 to 31.1 bales $\mathrm{hr}^{-1}$.

For other balers and forest species the results were heterogeneous and most of them below those in this study. This applies to Patterson et al. (2008) with a John Deere 1490D baler on Pinus taeda, with a productivity between 13.8-36.1 bales $\mathrm{hr}^{-1}$; Laitila et al. (2013) on Picea abies between 39-43 bales $\mathrm{hr}^{-1}$; (Moskalik et al., 2016) on mix forest of Picea abies and Pinus sylvestris between 15.2-20.8 bales hr-1 ${ }^{-1}$ Spinelli et al. (2012a) (no species mentioned) with 10.4 bales $\mathrm{hr}^{-1}$; Canga et al. (2009) on Eucalyptus globulus with 26 bales hr-1; Meadows et al. (2009) on Pinus taeda between 24.2-33.4 bales hr-1; Spinelli et al. (2007) (no species mentioned) between 10-15 bales $\mathrm{hr}^{-1}$; Kärhä and Vartiamäki (2006) on Picea abies with 18.1 bales $\mathrm{hr}^{-1}$; Rummer et al. (2004) on Pinus contorta and Pinus ponderosa between 5 and 19 bales $\mathrm{hr}^{-1}$. On the other hand, Liška et al. (2011) with a 9:1 softwood hardwood relation recorded 4 bales $\mathrm{hr}^{-1}$, far below the previous. Andersson et al. (2000) in a Valmet WoodPac on Picea

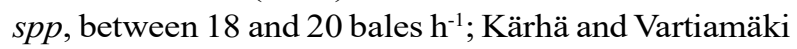
(2006) with a Pika RS 2000 and the Valmet WoodPac on Picea abies recorded 17.0 and 15.15 bales $\mathrm{hr}^{-1}$, respectively; Kärhä et al. (2011) in a Fixteri II for the same species, between 9.2 and 15.1 bales hr-1 $^{-1}$ Nuutinen et al. (2011) with the same machine and species, between 7 and 12 bales hr-1, and with a prototype ESM 901 Neff et al. (2006) between 11 and 17 bales $\mathrm{hr}^{-1}$.

Regarding the characteristics of the bales, this study registered an average length between 135 and $246 \mathrm{~cm}$ and an average diameter of $73 \mathrm{~cm}$. These results

Revista Árvore. 2017;41(5):e410512 are similar to those of Sánchez-García et al. (2015), with 244 and $78 \mathrm{~cm}$, respectively. With respect to mean volume of bale in this study, $1.03 \mathrm{~m}^{3}$ and an average dry weight of $236 \mathrm{~kg}$ were recorded (variation range of 134-369 kg), similar to results by Kärhä and Vartiamäki (2006) and Kärhä et al. (2011) with a Pika RS2000 baler, and those by Sánchez-García et al. (2015) with the same baler.

Common practice in Chile for harvesting logging residues is to use excavators equipped with rakes to stack the residues - and a grappler skidder that transports residues to the side of the road. Subsequently, in a deferred operation, they are chipped with a mobile crusher and loaded onto trucks for transport to processing plants. Acuña et al. (2017) evaluated the harvests of residues of Pinus radiata under these conditions on 19 forest farms, obtaining an average of $28.17 \mathrm{Mg} \mathrm{ha}^{-1}$ of dry biomass. However, these figures are below those registered in the present study, which reached an average of 46.92 and $34.32 \mathrm{Mg} \mathrm{ha}^{-1}$ of dry biomass for both types of the evaluated tasks.

Results obtained from the present study can gain importance in scenarios of similar conditions (e.g., species, type of harvest, conditions of residues, etc.). Further, it should be expected that harvests with this type of residue densification equipment can positively impact productivity in other harvest conditions. Yet, along with an improvement in diversification, sustainability should be evaluated and demonstrated given the potentially high impact these tasks have on soils from a physical, biological and nutritional angle (Kelting et al., 1999). Additionally, potential impacts on water quality and sedimentation of streams and rivers should 
be evaluated, which is critical to validate the sustainability of biomass harvesting practices (Sabourin et al., 1992). In Chile, this milestone becomes yet more sensitive given the location of forest plantations in mountainous areas and with high steeps, because often high agricultural intensity has been present and altered plantations resilience or ability to recover from damages (Schlatter and Gerding, 1995).

\section{CONCLUSIONS}

The effectiveness of an ENFO-2000 baler mounted on a forwarder under two harvesting systems of residual biomass of stands of Eucalyptus globulus (with and without bark), collected under the cut-to-length harvesting system was evaluated. Significant differences arose in comparison with type of harvesting system and mean of bales, and between type of harvesting system and mean baling time. Results indicate that the recovery of logging residues in Eucalyptus globulus with bark improves the baling system, increasing the density of bales and therefore containing a significantly dryer biomass.

\section{REFERENCES}

Acuña E, Cancino J, Rubilar R, Silva L. Volume, physical characteristics and costs of harvest residue utilization of Pinus radiata as an energetic source.Custos e@gronegócio Online. 2017;13(1):442-63.

Acuña E, Mena P, Torres C, Cancino J. ForestTime: una aplicación móvil para el estudio de tiempos de trabajo de maquinaria forestal através de teléfonos inteligentes. Bosque. 2013;34(3):359-66. http://dx.doi.org/10.4067/S071792002013000300012 .

Andersson G, Nordén B, Raida J, Åstrand C. Composite residue logs cut wood-fuel costs. Uppsala: SkogForsk; 2000. p. 11-4. Results No. 1.

Asikainen A, Ranta T, Laitala J. Large-scale forest fuel procurement. In: Pelkonen P, Hakkila $P$, Karjalainen T, Schlamadinger B, editors. Wood biomass as an energy source: challenges in Europe. Joensuu: European Forest Institute; 2001. p. 73-78.

Björheden R, Thompson MA. An international nomenclature for forest work study. In:
Proceedings of the IUFRO 1995 20th World Congress; 1995; Tampere, Finland. Maine: University of Maine; 1995. p. 190-215. Subject Area S3.04.

Brand MA, Stähelin TSF, Ferreira JC, Neves MD. Produção de biomassa para geração de energia em povoamentos de Pinus taeda L. com diferentes idades. Rev Arvore. 2014;38(2):353-60. http:// dx.doi.org/10.1590/S0100-67622014000200016.

Bustos O, Egan A, Hedstrom W. A comparison of residual stand damage along yarding trails in a group selection harvest using four different yarding methods. North J Appl For. 2010;27(2):56-61.

Bustos O, Egan A. A comparison of soil compaction associated with four ground-based harvesting systems. North J Appl For. 2011;28(4):194-8.

Canga E, Vivas A, Sánchez S, Alonso M, Álvarez E, Majada J. Estudio comparativo de dos empacadoras de residuos forestales en el norte de España. Progreso Forestal. 2009;19:36-42.

Chlebowski K, Jab ${ }^{3}$ oñski K. Bundling of logging residues: a new method to use biomass for energy purposes. Sylwan. 2012;156(4):315-20.

Cuchet E, Roux P, Spinelli R. Performance of a logging residue bundler in the temperate forests of France. Biomass Bioenergy. 2004;27(1):31-9. http://dx.doi.org/10.1016/j.biombioe.2003.10.006.

Earl JA. Slash bundler performance in Southeastern Arkansas [thesis]. Monticello: University of Arkansas at Monticello, Department of Forest Resources; 2006.

European Biomass Association. European Bioenergy Outlook 2012. Brusels: AEBIOM; 2012. 124 p.

European Commission. A policy framework for climate and energy in the period from 2020 to 2030. Brussels: European Commission; 2014. 18 p. $\mathrm{COM} / 2014 / 015$ final.

Hunter A, Boyd J, Palmer H, Allen J, Browne M. Transport of forest residues to power stations. In: Proceedings of the Forestry Engineering Group International Conference; 1999; Edinburgh, Scotland. Oregon: Forest Engineer; 1999. p. 9.

Revista Árvore. 2017;41(5):e410512 
Husch B, Beers TW, Kershaw JA. Forest mensuration. 4th ed. New York: Wiley; 2003. 443 p.

Intergovernmental Panel on Climate Change. Bioenergy. In: Edenhofer O, Pichs-Madruga R, Sokona Y, Seyboth K, Kadner S, Zwickel T, et al. IPCC special report on renewable energy sources and climate change mitigation. Cambridge: Cambridge University Press; 2011. p. 209-332. http://dx.doi.org/10.1017/CBO9781139151153.006.

Johansson J, Liss JE, Gullberg T, Björheden R. Transport and handling of forest energy bundles: advantages and problems. Biomass Bioenergy. 2006;30(4):334-41. http://dx.doi.org/10.1016/ j.biombioe.2005.07.012.

Kärhä K, Jylhä P, Laitila J. Integrated procurement of pulpwood and energy wood from early thinnings using whole-tree bundling. Biomass Bioenergy. 2011;35(8):3389-96. http://dx.doi.org/ 10.1016/j.biombioe.2010.08.068.

Kärhä K, Vartiamäki T. Productivity and costs of slash bundling in Nordic conditions. Biomass Bioenergy. 2006;30(12):1043-52. http://dx.doi.org/ 10.1016/j.biombioe.2005.12.020.

Kelting DL, Burger JA, Patterson SC, Aust WM, Miwa M, Trettin CC. Soil quality assessment in domesticated forests: a southern pine example. For Ecol Manage. 1999;122(1-2):167-85. http:// dx.doi.org/10.1016/S0378-1127(99)00040-7.

Laitila J, Kärhä K, Jylhä P. Time consumption models and parameters for off- and on-road transportation of whole-tree bundles. Balt For. 2009;15(1):105-14.

Laitila J, Kilponen M, Nuutinen Y. Productivity and cost-efficiency of bundling logging residues at roadside landing. Croat J For Eng. 2013;34(2):175-87.

Lindholm EL, Berg S, Hansson PA. Energy efficiency and the environmental impact of harvesting stumps and logging residues. Eur J For Res. 2010;129(6):1223-35. http://dx.doi.org/10.1007/ s10342-010-0412-1.

Lindroos O, Matisons M, Johansson P, Nordfjell T. Productivity of a prototype truck- mounted logging residue bundler and a road-side bundling system. Silva Fenn. 2010;44(3):547-59. http:// dx.doi.org/10.14214/sf.148.

Liška S, Klvaè R, Skoupý A. Evaluation of John Deere 1490D operation phase in typical conditions of the Czech Republic. J Sci. 2011;57(9):394-400. http://dx.doi.org/10.17221/21/2010-JFS.

Magagnotti N, Spinelli R, editors. Good practice guidelines for biomass production studies. 1st ed. Sesto Fiorentino: CNR IVALSA; 2012. p. 52.

Meadows S, Gallagher T, Mitchell D. A new slash bundling concept for use in a southern US logging system. For Prod J. 2011;61(3):210-5. http://dx.doi.org/10.13073/0015-7473-61.3.210.

Meadows S, Gallagher T, Mitchell D. Optimizing the use of a John Deere bundling unit in a southern logging system. Orlando: Society of American Foresters; 2009. p. 8.

Moskalik T, Sadowski J, Zastocki D. Some technological and economic aspects of logging residues bundling. Sylwan. 2016;160(1):31-9.

Neff A, Nelles M, Kuprat H, Guba E, Hansen L, Brunner J. Erzeugung und einsatz von, mittels bündler und verschiedener zerkleinerungstechnik erzeugter, hackschnitzel endbericht. Göttingen: FG Technischer Umweltschutz der Universität Göttingen; 2006.

Nuutinen Y, Kärhä K, Laitila J, Jylhä P, Keskinen S. Productivity of whole-tree bundler in energy wood and pulpwood harvesting from early thinnings. Scand J For Res. 2011;26(4):329-38. http://dx.doi.org/10.1080/02827581.2011.568952.

Patterson DW, Pelkki MH, Steele PH. Productivity of the John Deere slash bundler in removing in-forest residues from pine harvest sites in the mid-South: Four case studies. For Prod J. 2008;58(7-8):31-6.

Rummer B, Len D, O’brien O. Forest residue bundling project: new technology for residue removal. Auburn: USDA Forest Service Forest Operations Unit, Southern Research Station; 2004 20 p. Report unnumbered.

Sabourin M, Puttock GD, Richardson J. International Energy Agency Bioenergy

Revista Árvore. 2017;41(5):e410512 
Agreement Progress and Achievements 1989-1991 Forest management strategies for producing wood for energy from conventional forestry systems. Biomass Bioenergy. 1992;2(1):105-19. http:// dx.doi.org/10.1016/0961-9534(92)90093-6.

Sánchez S, Canga E, Picchi G, Nati C. Analysis of the procurement system of Eucalyptus residues with bundling technology. Pushing the boundaries with research and innovation in forest engineering. In: Proceedings of the 44th International Symposium on Forestry Mechanisation (FORMEC 2011); 2011; Graz, Austria. Graz: FORMEC; 2011.p. 5.

Sánchez-García S, Eliasson L, Tolosana E, Majada J, Canga E. Evaluation of technological improvements in bundling units for the collection of eucalyptus logging residues on steep terrain in Spain. For Syst. 2015;24(2):e030. http://dx.doi.org/ $10.5424 / \mathrm{fs} / 2015242-06034$.

Sas Institute Inc. SAS ${ }^{\circledR}$ University Edition: Installation Guide for Windows. Cary: SAS Institute Inc.; 2014. 21 p.

Schlatter J, Gerding V. Método de clasificación de sitios para la producción forestal, ejemplo en Chile. Bosque. 1995;16(2):13-20. http://dx.doi.org/ 10.4206/bosque.1995.v16n2-02.
Spinelli R, Lombardini C, Magagnotti N. Annual usage and long-term productivity of a truckmounted slash bundler under mountain conditions. Eur J For Res. 2012a;131(3):821-7. http://dx.doi.org/10.1007/s10342-011-0555-8.

Spinelli R, Magagnotti N, Picchi G. A supply chain evaluation of slash bundling under the conditions of mountain forestry. Biomass Bioenergy. 2012b;36(6):339-45. http://dx.doi.org/10.1016/ j.biombioe.2011.11.001.

Spinelli R, Magagnotti N. Logging residue bundling at the roadside in mountain operations. Scand J For Res. 2009;24(2):173-81 . http:// dx.doi.org/10.1080/02827580902806593.

Spinelli R, Magagnotti N. A tool for productivity and cost forecasting of decentralised wood chipping. For Policy Econ. 2010;12(3):194-8. http:// dx.doi.org/10.1016/j.forpol.2009.10.002.

Spinelli R, Nati C, Magagnotti N. Recovering logging residue: Experiences from the Italian Eastern Alps. Croat J For Eng. 2007;28(1):1-9.

Van Daele P. Work study in forestry. In: Owen DL, editor. South African forestry handbook. Pretoria: South African Institute of Forestry; 2000. p. 407-13. 